\title{
Genetic Protection of Soft Wheat from Diseases in the Southern Ural of Russia and Virulence Variability of Foliar Pathogens
}

\author{
Igor Kushnirenko ${ }^{1}$, Ekaterina Shreyder ${ }^{1}$, Nadezhda Bondarenko ${ }^{1}$, Ekaterina Shaydayuk ${ }^{2}$, \\ Nadezhda Kovalenko ${ }^{2}$, Julia Titova ${ }^{2}$ and Elena Gultyaeva ${ }^{2, * \text { (D) }}$ \\ 1 Chelyabinsk Scientific Research Institute of Agriculture, 456404 Timiryazevskiy, Russia \\ ikush2001@mail.ru (I.K.); shreyder11@mail.ru (E.S.); bondarenko_np61@mail.ru (N.B.) \\ 2 All Russian Research Institute of Plant Protection, 196608 St. Petersburg, Russia; eshaydayuk@bk.ru (E.S.); \\ nadyakov@mail.ru (N.K.); juli1958@yandex.ru (J.T.) \\ * Correspondence: egultyaeva@vizr.spb.ru
}

\section{check for} updates

Citation: Kushnirenko, I.; Shreyder, E.; Bondarenko, N.; Shaydayuk, E.; Kovalenko, N.; Titova, J.; Gultyaeva, E. Genetic Protection of Soft Wheat from Diseases in the Southern Ural of Russia and Virulence Variability of Foliar Pathogens. Agriculture 2021, 11, 703. https://doi.org/10.3390/ agriculture 11080703

Academic Editor: Olga

Silvestrovna Afanasenko

Received: 23 June 2021

Accepted: 25 July 2021

Published: 26 July 2021

Publisher's Note: MDPI stays neutral with regard to jurisdictional claims in published maps and institutional affiliations.

Copyright: (c) 2021 by the authors. Licensee MDPI, Basel, Switzerland. This article is an open access article distributed under the terms and conditions of the Creative Commons Attribution (CC BY) license (https:// creativecommons.org/licenses/by/ $4.0 /)$

\begin{abstract}
The southern Ural is consistently among the 10 best regions in Russia for agricultural production, including wheat. Breeding in the Chelyabinsk Research Institute of Agriculture aims to develop wheat cultivars genetically protected from the main diseases (leaf and stem rust, septoria leaf blotch and tan spot). The genes for resistance to leaf rust, Lr1, Lr9, Lr10 and Lr26/Sr31, alone or in combination, are widespread in cultivars grown in the southern Ural. In 2012, a new wheat cultivar, Chelyaba 75, was proposed for commercial production in the southern Ural, being highly resistant to leaf rust with the highly effective genes $L r S p$ and $S r S p$ transferred from the cuckoo line with the genetic material Aegilops speltoides. Isolates virulent to cv. Chelyaba 75 were not found in Russian populations of Puccinia triticina. Additionally, for a long period, genes Lr29, Lr 41, Lr42, Lr45, Lr47, Lr50, Lr51, Lr53 and Lr57 were characterized by high efficiency. Virulence frequencies to other $L r$ genes vary annually, but no races with new virulence have been identified. The resistance of lines with the Sr31 and Sr24 genes indicates that the Puccinia graminis population does not contain genotypes with the potentially damaging race Ug99. Mixed septoria and tan spot infections occurred in the southern Ural, with the latter dominating. Races producing the exotoxin ToxA are widely distributed in Pyrenophora tritici-repentis populations. Two causal agents of septoria leaf blotch (Parastagonospora nodorum and P. avenae f. sp. tritici) occur in the region, with the first dominating. Aggressiveness of $P$. nodorum isolates to wheat cultivars was higher than that of $P$. avenae f. sp. tritici. All Parastagonospora isolates showed the presence of the SnTox3 marker. SnToxA and SnTox1 markers were found in P. nodorum isolates, usually separately, but in one isolate, these genes were found together. The analysis of the genetic diversity of wheat cultivars grown in the southern Ural, and the pathogenic complex present, indicate that pathogens continuously evolve under the influence of the host plant.
\end{abstract}

Keywords: Parastagonospora avenae f. sp. tritici; Parastagonospora nodorum; Puccinia graminis; Puccinia triticina; Pyrenophora tritici-repentis; resistance; Triticum aestivum

\section{Introduction}

The Ural region of Russia is located in the southern part of the Ural Mountains in the center of the Eurasian continent, a great distance from seas or oceans, both of which contribute to its climate and relief. The Ural ridge divides the region into the Cis-Urals and Trans-Urals. The Chelyabinsk Oblast is in the southern Trans-Urals and is characterized by the greatest contrast in soil and climatic conditions [1]. The main features of its climate are cold, long winters with frequent snowstorms and moderately warm summers with periodically recurring droughts, especially in the south. In winter, the Trans-Urals is influenced by the Asian baric maximum, which is associated with the removal of cold continental air. The meridional ridge of the Ural Mountains and the openness of the TransUrals towards the Arctic Ocean contribute to the frequent intrusion of the Arctic air, which 
is characterized by low temperatures and low moisture content. In the summer, warm continental air from Kazakhstan and Central Asia enters the southern regions, bringing hot, dry weather [2].

The distribution of precipitation in the southern Ural varies greatly from year to year and during the cropping season. One of the peculiarities of the region is that the maximum precipitation in July is in the first half of summer, but overall summer can be relatively arid $[3,4]$.

Despite the contrasting climatic conditions, in the 2010s, the Chelyabinsk was consistently among the 10 best regions in Russia for agricultural production. The total area sown to various agricultural crops represents $2-3 \%$ of the total cropping area of Russia. In the region, soft and durum wheat, barley, oats, rye, triticale and millet are grown [5]. The largest proportion of cropping in the region is soft wheat (mostly spring wheat), comprising $40-50 \%$ of the area sown. In terms of area sown to soft wheat, the Chelyabinsk region is in the top 10 regions of Russia [6].

It has been shown that yield losses in various wheat cultivars are due to excess moisture in the second half of the growing season, leading to $12-65 \%$ lower yields [7]. This is due to the lodging of plants and the damaging effects of leaf diseases, among which leaf rust dominates. Along with these stresses during the period of high moisture supply, enzyme-mycotic seeds' depletion (EMSD) is of great importance. Therefore, for conditions in the southern Ural, it is important to have genotypes that are simultaneously drought-tolerant and resistant to lodging and diseases caused by an excess of moisture in the second half of the growing season.

Until recently, leaf rust was the main contributor to a damaging pathogenic complex in the region. In some conducive years, the yield losses in wheat were more than $35 \%$ [8]. From mid-2010, the severity of stem rust and leaf blotches (septoria leaf blotch and tan spot) outbreaks began to increase.

The majority of cultivars grown in the Chelyabinsk region were developed by the Chelyabinsk Research Institute of Agriculture (ChRIA). For example, in 2020, these represented $52 \%$ of the total cropping. The leading cultivars (cv.) in terms of area sown have been cv. Chelyaba 75, Chelyaba rannyaya, Erythrospermum 59 and Duet.

Breeding of soft spring wheat at ChRIA commenced in 1937 and has two methodological periods. The first period (1937-1960) was characterized by the use of mainly local wheat cultivars and their hybridization. During this period, the cv. Iskra, Vesna and others were developed. These local cultivars of soft spring wheat had drought tolerance, but lacked the economically important traits of resistance to lodging and diseases due to their long stems.

Since the 1960s, the most valuable domestic and foreign genotypes of spring wheat were used in crossbreeding. The widely used materials were cv. Saratovskaya 29, Selkirk, Saunders, Ruby, Acadia, Rescue $\times$ Mida (Canada), Klein H-75, Klein Lucero (Argentina), Lee, DC II (USA), Kärn II, Svenno (Sweden) and others from the collection of N.I. Vavilov All-Russian Institute of Plant Genetic Resources.

Since 1990, ChRIA has begun targeted selection for complex resistance to a combination of stress factors (drought, EMSD, leaf rust and lodging). For this, drought and EMSD-resistant cv. Eritrospermum 59, Izumrudnaya and Charkovskaya 12, as well as cv. Kvinta and Duet, combining EMSD-resistance with specific resistance to leaf rust, were widely used in crosses. Under the climatic conditions of the southern Ural, an awned spike has been shown to increase drought and moisture resistance in wheat. Wheat with awned spikes has a higher 1000 kernel weight under drought and overwatering, and is less affected by EMSD, which contributes to increased yield stability between years. Cultivars Erythrospermum 59, Duet and Chelyaba 2, and other breeding lines with awned spikes, have clear advantages over awnless forms $[7,8]$.

Breeding for resistance to leaf rust has a long history in the southern Ural, and it has been based on the strategy of producing cultivars with vertical resistance. The use of nonspecific disease resistance has been limited as it has a negative association with drought 
tolerance. In the mid-2010s, ChRIA, in conjunction with standard breeding for resistance to leaf rust, began using molecular markers and marker assistance selection (MAS).

\section{Cultivars and Promising Lines of Soft Spring Wheat Produced in ChRIA}

Since 1937, ChRIA breeders have produced and introduced to the region 40 cultivars, of which 17 are included in the State Register of Breeding Achievements (SRBA) as approved for use (Table 1). The widely sown cultivars in southern Ural and Western Siberia at different times were cv. Iskra, Vesna, Uralskaya 52, Rossiyanka, Erythrospermum 59, Niva 2, Duet and Chelyaba 75. The ecological optimums for Chelyabinsk cultivars have now shifted towards more efficient use of the moisture resource due to increased resistance to lodging, leaf rust, EMSD and other stresses.

Table 1. Cultivars of the Chelyabinsk Research Institute of Agriculture included in the State Register of Breeding Achievements (SRBA) and promising cultivars progressed to State Cultivar Testing (SCT).

\begin{tabular}{|c|c|c|c|c|c|}
\hline Cultivar & Pedigree & $\begin{array}{c}\text { Year of Involvement } \\
\text { in the SRBA/ } \\
\text { Transfer to SCT }\end{array}$ & Ripening Time & Grain Quality & Resistance Genes \\
\hline Iskra & $\begin{array}{l}\text { Milturum } 321 \times \\
\text { Kitchener }\end{array}$ & 1949 & late-ripe & weak & \\
\hline Vesna & - & 1961 & mid-ripe & weak & \\
\hline Ural'skaya 52 & $\begin{array}{l}\text { Cesium } 111 \times \\
\text { Lutescens } 324\end{array}$ & 1974 & mid-ripe & strong & \\
\hline Rossiyanka & Saunders $\times$ Svenno & 1981 & mid-ripe & strong & \\
\hline Uralochka & $\begin{array}{c}\text { Svenno } \times(\text { Lee } \times \text { Kenya } \\
\text { Farmer })\end{array}$ & 1987 & mid-ripe & strong & \\
\hline Eritrospermum 59 & Chayka $\times$ Irtyshanka 10 & 1994 & mid-ripe & strong & Lr10 \\
\hline Izumrudnaya & Waldron $\times$ Ural'skaya 52 & 1996 & mid-ripe & filler & Lr26/Sr31/Pm8/Yr9 \\
\hline Niva 2 & $\begin{array}{l}\text { Ps } 360 / 76 \times \\
\text { Irtyshanka } 10\end{array}$ & 1997 & mid-ripe & strong & \\
\hline Duet & $\begin{array}{c}\text { Eritrospermum } 59 \times \\
\text { (Tselinnaya } 20 \times \\
\text { ANK-02) }\end{array}$ & 2003 & mid-ripe & valuable & $\operatorname{Lr} 9 \operatorname{Lr} 10$ \\
\hline Chelyaba 2 & $\begin{array}{c}\{(\text { Tezpishar } \times \\
\text { Irtyshanka 10) } \times \\
\text { Irtushanka 10\} } \times \\
\text { Tselinnaya } 20 \times \\
\text { ANK-102) }\end{array}$ & 2005 & mid-early & valuable & Lr9 Lr10 \\
\hline Pamyati Ryuba & $\begin{array}{c}\text { Tertsiya } \times \\
\text { Eritrospermum } 19542\end{array}$ & 2006 & mid-ripe & valuable & Lr9 Lr10 \\
\hline $\begin{array}{c}\text { Chelyaba } \\
\text { yubileynaya }\end{array}$ & $\begin{array}{l}\text { Eritrospermum } 59 \times \\
\text { Tertsiya }\end{array}$ & 2010 & mid-late & filler & Lr9 Lr10 \\
\hline Chelyaba stepnaya & $\begin{array}{l}\text { Eritrospermum } 59 \times \\
\text { Tertsiya }\end{array}$ & 2011 & mid-early & valuable & Lr9 Lr10 \\
\hline Chelyaba 75 & $\begin{array}{c}\text { Chernyava } 13 \times \\
\text { Eritrospermum } 21338\end{array}$ & 2012 & mid-ripe & valuable & Lr1 Lr10 LrSp \\
\hline Ural'skaya kukushka & $\begin{array}{l}\text { Lutescens } 4 \times \\
\text { Tulunskaya10 } \times \\
\text { Lutescens } 22178\end{array}$ & 2016 & mid-early & filler & \\
\hline Chelyaba rannyaya & Chelyaba $2 \times$ ANK-104 & 2016 & early-ripe & filler & $\operatorname{Lr} 9 \operatorname{Lr} 10$ \\
\hline Silach & $\begin{array}{c}\text { Lutescens } 210 / 99-10 \times \\
\text { Eritrospermum } 23090\end{array}$ & 2020 & mid-late & filler & $\begin{array}{c}\text { Lr10 Lr9 } \\
\text { Lr26/Sr31/Pm8/Yr9 }\end{array}$ \\
\hline
\end{tabular}


Table 1. Cont.

\begin{tabular}{|c|c|c|c|c|c|}
\hline Cultivar & Pedigree & $\begin{array}{c}\text { Year of Involvement } \\
\text { in the SRBA/ } \\
\text { Transfer to SCT }\end{array}$ & Ripening Time & Grain Quality & Resistance Genes \\
\hline Chelyaba 80 & $\begin{array}{c}\text { Cuckoo line } 210 \times \\
\text { Rossiyanka } \times \\
\text { Novosibirskaya } 15\end{array}$ & SCT 2017 & mid-late & valuable & $L r S p$ \\
\hline Il'menskaya 2 & $\begin{array}{c}\text { Chelyaba } 75 \times \\
(\text { Chelyaba } 2 \times \text { Fori } 7)\end{array}$ & SCT 2018 & mid-early & valuable & $L r S p$ \\
\hline Odintsovskaya & Chelyaba $75 \times$ ANK-17B & SCT 2018 & early-ripe & valuable & $L r S p$ \\
\hline Chelyabinka & Vatan $\times$ Duet & SCT 2021 & mid-ripe & valuable & $\operatorname{Lr} 9 \operatorname{Lr} 26$ \\
\hline
\end{tabular}

Most of the cultivars grown in the southern Ural before the 2000s were characterized by a high level of susceptibility to leaf rust, and many of them are no longer grown commercially, with the exception of cv. Erythrospermum 59, given that it is equivalent to many modern cultivars in grain quality and resistance to hydrological and hydrothermal stresses. Cultivar Erythrospermum 59 is simultaneously resistant to drought and excessive moisture, has high resistant to lodging and is not subject to EMSD. It is also tolerant to leaf rust, but susceptible to stem rust, septoria leaf blotch and other leaf spots.

In the 1999-2000s, the first cultivars of spring wheat, cv. Kvinta and Duet, resistant to leaf rust, were developed by ChRIA. This resistance was due to the $\operatorname{Lr} 9$ gene, which was highly efficient at that time. Cultivar Kvinta is no longer widely grown, however cv. Duet remains useful for commercial wheat production and is the standard in the midseason group of cultivars, and it is distinguished by soft grain threshing and yield. Cultivars Duet and Kvinta, and the breeding lines developed from them, have been widely used in subsequent crossbreeding. This has led to the wide distribution of the Lr9 gene across many modern cultivars developed for the southern Ural (viz., Chelyaba 2, Pamyati Ryuba, Chelyaba yubileynaya, Chelyaba rannyaya, Chelyaba stepnaya and Chebarkul'skaya 3) [8].

Most of these cultivars (e.g., Chelyaba 2, Pamyati Ryuba, Chelyaba yubileynaya and Chelyaba rannyaya) in the contrasting weather conditions of the southern Ural are distinguished by stable productivity, due to their resistance to drought, seed-shattering, preharvest sprouting and lodging. They produce grain with high and stable protein and gluten content. Cultivar Chelyaba 2 is distinguished not only by high protein and gluten content but also high iron content. These characteristics led to the widespread use of these cultivars in the southern Ural. Since the 2010s, these and other cultivars have been widely grown in neighboring regions (Western Siberia and Kazakhstan). Production of a high proportion of cultivars with the $\mathrm{Lr} 9$ gene led to the emergence of pathogen virulence in the southern Ural and Western Siberia in 2007 [9]. Since the mid-2010s, all Chelyabinsk cultivars previously protected by Lr9 have been severely affected by leaf rust, which precipitated the search for and inclusion into breeding programs of the new resistance donors having effective $\mathrm{Lr}$ genes.

Attempts were also made by ChRIA to extend the useful life of cultivars with Lr9. As a result, a spring wheat $\mathrm{cv}$. Silach was developed that along with Lr9 also has Lr26/Sr31/Pm8/Yr9 genes. In 2020, cv. Silach was included in the SRBA and recommended for cultivation in the whole Ural region of Russia. This cultivar has a high resistance to leaf and stem rusts as both seedlings and adult plants. It is resistant to drought and lodging, like all other Chelyabinsk cultivars, as well as resistant to seed-shattering and preharvest sprouting. This is due to the fact that Russian populations of the leaf rust pathogen are not simultaneously virulent to $L r 9$ and $L r 26$. However, in pathogen populations, there is widespread occurrence of virulence to $L r 9$ along with $L r 1, L r 2 a, L r 2 b, L r 2 c, L r 3 a, L r 3 b g$, Lr3ka, Lr10, Lr14a, Lr14b, Lr15, Lr17, Lr18, Lr20 and Lr30 [10,11].

In the 2000s, to expand genetic diversity of resistance to leaf rust, alien donors began to be widely used by ChRIA. One of them was a cuckoo-type line with some Aegilops speltoides genetic background. These lines were developed at the N.I. Vavilov All-Russian 
Institute of Plant Genetic Resources from crosses and backcrosses with soft wheat of the complex-resistant amphidiploid Triticum dicoccum $\times$ Ae. speltoides, and they carried a block of effective $L r$ and $S r$ genes linked to the gametocidal gene (Gc). The $G c$-gene expression leads to the elimination of gametes carrying the recessive $g c$ allele in the heterozygous sporophyte tissues. Recessive alleles linked to it ( $l r$ and $s r$ ) are also eliminated, and as a result, F1 plants are semi-sterile, and in F2 they are homozygous for resistance [12]. The $\mathrm{Gc}$-gene was named cuckoo. Interest in $\mathrm{Lr}$ and $\mathrm{Sr}$ gene identification in cuckoo-type lines considered for selection is associated with their linked inheritance of resistance to two damaging pathogens and with a genetic mechanism of selection for resistance (Gc-gene). The presence of the Gc-gene in the block excludes the use of established hybridological analysis; therefore, molecular screening is an alternative method for identifying these genes. Ibragimova et al. [13] identified the gametocidal gene of the cuckoo-type lines as Gc1 and determined its localization on chromosome 2B.

In 2012, a new wheat cultivar, Chelyaba 75, which is highly resistant to leaf rust having the highly efficient gene $\operatorname{LrSp}(+\operatorname{Lr} 1$ and $\operatorname{Lr} 10)$ transferred from the cuckoo line with the genetic material Ae. speltoides, was proposed for commercial production in the southern Ural [14]. Adonina et al. [15], using molecular-cytology analysis by C-banding and fluorescence in situ hybridization, revealed that cv. Chelyaba 75 has a 2DS.2SL translocation from Ae. speltoides. Using molecular markers, Lr28, Lr47 or Lr51 genes (derived from Ae. speltoides) were not detected in this cultivar. Using BCD260F/35R and BE50070 markers in cv. Chelyaba 75, no amplification products were detected, indicating the absence of the $L r 35 / S r 39$ genes, whereas a positive result was obtained with the $S r 39 \neq 22 \mathrm{r}$ marker. Earlier, it was found [16] that the Sr39 $\neq 22 \mathrm{r}$ marker is not specific enough to identify these genes. The Lr35/Sr39 genes were also detected in some samples derived from Ae. speltoides or in samples with other alien genetic backgrounds (e.g., Ttriticum timopheevii). In addition, the Lr35/Sr39 belong to the group of adult plant resistance genes and provide resistance in the later stages of plant growth. Additionally, cv. Chelyaba 75 is characterized by high resistance in seedlings and adult plants (Figure 1).

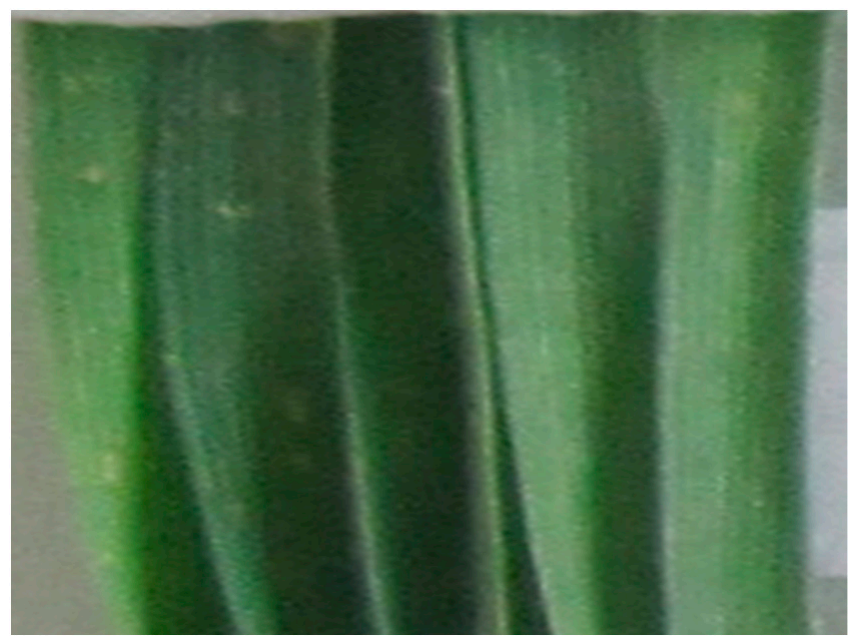

(a)

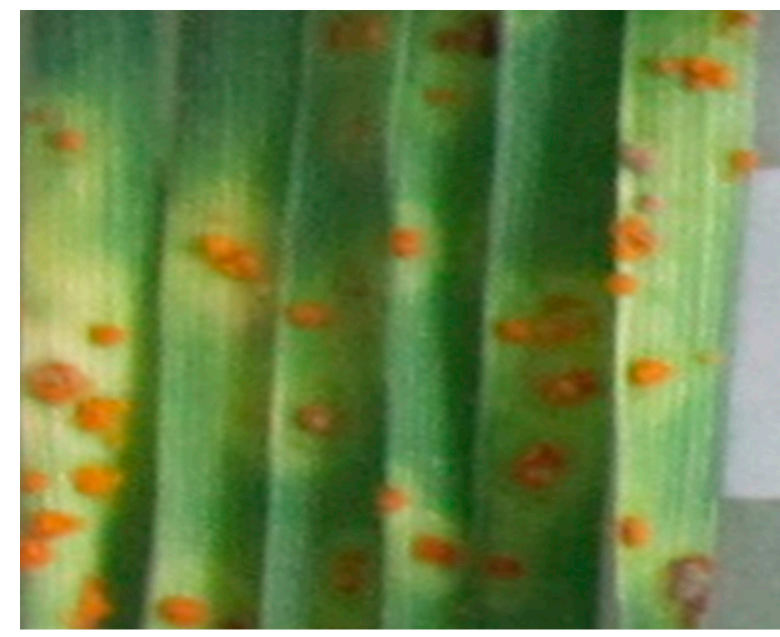

(b)

Figure 1. Reaction of cv. Chelyaba 75 (a) and line TcLr35 (b) to leaf rust at the seedling stage.

Along with the Sr39 $\neq 22$ r marker, the S13-R16 marker of the Lr66 gene (=LrS13) was also detected in cv. Chelyaba 75. The source of the Lr66 gene is an introgressive line S13 (W84-17//CS7*/Ae. speltoides). Homoeologous group 3 chromosomes microsatellite analyses revealed that the $\mathrm{S} 13$ introgressed region in line 8029 occurs on chromosome $3 \mathrm{~A}$, and it possibly includes the complete 3AS arm (3Ap) and a proximal region of the long arm (q arm) [17]. Since the localization of the $L r S 13$ gene differs from that the resistance gene in cv. Chelyaba 75 ( $L r S p)$, it can be assumed that they are not identical. 
Isolates virulent on cv. Chelyaba 75 were not found in Russian populations of Puccinia triticina, despite the extended growing of this cultivar (about 10 years) and the expansion of its sown area. Cultivar Chelyaba 75 is also characterized by resistance to stem rust and common bunt as well as to lodging. In terms of grain quality, it meets the requirements for valuable and strong wheat. Currently, it is the only cultivar in Russia protected by the new LrSp gene, which differs from the known effective gene obtained from Ae. speltoides. In extensive environmental trials in various regions of Russia and Kazakhstan conducted under the Kazakhstan-Siberia Network for Spring Wheat Improvement program, cv. Chelyaba 75 has shown exemplary performance in disease resistance and economically valuable characteristics [18]. New cultivars with the $\mathrm{LrSp}$ gene (cv. Chelyaba 80, Odintsovskaya and Chelyabinka) have now progressed to State Cultivar Testing.

In the 2000s, ChRIA began to use new donors and lines in breeding with alien genes Lr22a Lr24, Lr21, Lr25, Lr38, Lr47 (Pavon), Lr48 (CSP44), Lr49 (VL404) and others. A new breeding material of soft spring wheat has been created, combining disease resistance with adaptability to adverse environmental factors, high yield and grain quality $[14,19]$. Molecular analysis showed a high genetic diversity of all lines in terms of resistance to leaf and stem rusts. Many of the breeding lines have a complexed resistance to the foliar diseases (leaf and stem rust, powdery mildew and blotches) and carry resistance genes previously unused in Russian wheat cultivars (e.g., Lr21 and Lr24). More important examples of them are presented in Table 2.

The most promising lines are highly resistant to leaf and stem rusts at both seedling and adult plant stages. However, the Lut. 26534 (Lutescens) introgressive line is only resistant to leaf rust in the field. Using molecular markers, the known adult plant resistance genes were not detected. Only low effective $L r$ genes ( $L r 1, L r 3, L r 10$ and $L r 26)$ alone or in combination were detected in higher rust-resistant lines, M. 26690 (Miltrum), Lut. 26720 and Er. 26762 (Eritrospermum). Therefore, it is possible that these lines have unknown $L r$ genes not detectable with the available molecular markers.

Additionally, some promising wheat lines range from moderately susceptible to moderately resistant to tan spot. The severity of this disease has been increasing in the southern Ural since mid-2010 [10,14]. No significant differences in cultivar reaction were found in response to inoculation by Pyrenophora tritici-repentis (Ptr) races that produce different toxins (ToxA, ToxB and ToxA-) (Table 2). The Tsn1 gene in wheat genotypes confers sensitivity to ToxA produced by pathogens, and compatible Tsn1-ToxA interactions contribute to susceptibility in both systems. The dominant marker Xfcp623 developed from the Tsn1 gene was used to infer the allelic status at Tsn1 [20]. Genotyping of the wheat accessions developed by ChRIA with the PCR marker Xfcp623 indicated that only the introgressive line Lut. 26720 had the dominant allele of the Tsn1-gene. However, this line showed a resistant reaction to ToxA+ isolates and others tested, which indicates the presence of additional genes responsible for its resistance. Similar results were obtained with molecular testing that was more representative of ChRIA breeding material. Of 65 lines, only two introgressive wheat lines were found to have the marker Xfcp623. One of these was Lut. 26721, which is similar in pedigree to Lut. 26720. This indicates that most ChRIA breeding lines have resistance to Ptr races producing ToxA.

Most of the introgressive lines were susceptible to septoria leaf blotch at the seedling stage. In the field, a high level of resistance was observed in Lut. 26708. This line was selected from cv. Tulaykovskaya 5, having genetic material from Thinopyrum intermedium (syn. Agropyron intermedium). Wheat genotypes with cv. Tulaykovkaya 5 in their pedigree are highly resistant to rusts and other foliar diseases. Gene Lr6Agi2 identified in this line has a substitution in wheat chromosome 6D from chromosomes 6Agi and 6Agi2, which belong to the J (=E) sub-genome of Th. intermedium [21]. Virulence to Lr6Agi2 has not been recorded in Russia. 


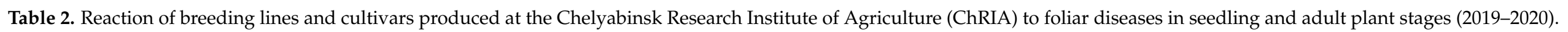

\begin{tabular}{|c|c|c|c|c|c|c|c|c|c|c|c|c|c|c|}
\hline \multirow{3}{*}{$\begin{array}{l}\text { Wheat Line/ } \\
\text { Cultivar }\end{array}$} & \multirow{3}{*}{$\begin{array}{c}\text { Idenified } \\
\text { Resistance Genes }\end{array}$} & \multicolumn{9}{|c|}{ Reaction Type to Foliar Wheat Pathogens at the Seedling Stage } & \multicolumn{4}{|c|}{ Disease Severity in the Field (\%) } \\
\hline & & \multicolumn{3}{|c|}{ Puccinia triticina } & \multirow{2}{*}{$\begin{array}{c}\begin{array}{c}\text { Puccinia } \\
\text { graminis }\end{array} \\
\text { Pg1 }\end{array}$} & \multirow{2}{*}{$\begin{array}{c}\begin{array}{c}\text { Parastagonospora } \\
\text { nodorum }\end{array} \\
\mathrm{Pn}\end{array}$} & \multirow{2}{*}{$\begin{array}{c}\text { Parastagonospora } \\
\text { avenae f. sp. tritici } \\
\mathrm{Pa}\end{array}$} & \multicolumn{3}{|c|}{ Pyrenophora tritici-repentis } & \multirow{2}{*}{$\begin{array}{l}\text { Stem } \\
\text { Rust }\end{array}$} & \multirow{2}{*}{$\begin{array}{l}\text { Leaf } \\
\text { Rust }\end{array}$} & \multirow{2}{*}{$\begin{array}{c}\text { Septoria Leaf } \\
\text { Blotch }\end{array}$} & \multirow[t]{2}{*}{$\begin{array}{c}\text { Tan } \\
\text { Spot }\end{array}$} \\
\hline & & PtK1 & PtK2 & PtK3 & & & & $\begin{array}{c}\text { Ptr } \\
\text { ToxA+ }\end{array}$ & $\begin{array}{c}\text { Ptr } \\
\text { ToxA- }\end{array}$ & $\begin{array}{c}\text { Ptr } \\
\text { ToxB+ }\end{array}$ & & & & \\
\hline Lut. 26534 & & 3 & $0-1$ & 3 & $3-4$ & 5 & $3-4$ & $2-3 / 2-3$ & $2-3 / 2-3$ & $1-2 / 1-2$ & $\begin{array}{l}1-5 \\
\text { MS }\end{array}$ & 0 & 5 & 1 \\
\hline Er. 26596 & $\begin{array}{c}\text { Lr10 LrSp/SrSp } \\
\text { Lr34/Yr18/Sr57/Pm38 }\end{array}$ & 0 & 0 & 0 & $1-2$ & $2-3$ & $2-3$ & $2-3 / 2-3$ & $2-3 / 2-3$ & $2-3 / 2-3$ & $01 \mathrm{MR}$ & 0 & 5 & 1 \\
\hline Lut. 26708 & Lr3 Lr10 Lr6Agi2 & $0-1$ & 0 & $0-1$ & $0-1$ & $3-4$ & 3 & $3 / 3-4$ & $2-3 / 2-3$ & $2-3 / 2-3$ & 0 & 0 & 0 & 0 \\
\hline Lut. 26720 & Lr1 Lr3 Lr10 Tsn1 & 3 & 3 & 3 & $0-1$ & 5 & & $2-3 / 2-3$ & $2 / 2$ & $1 / 1$ & 0 & 0 & 5 & 0 \\
\hline Er. 26725 & Lr24/Sr24 & 0 & 0 & 0 & 0 & 5 & 4 & $1-2 / 1-2$ & $3 / 3$ & $1-2 / 1$ & 0 & 0 & 5 & 10 \\
\hline Ferr. 26727 & Lr10 Lr24/Sr24 & 0 & 0 & 0 & $0-1$ & 5 & 4 & $1-2 / 1-2$ & $1-2 / 1-2$ & $1-2 / 1-2$ & 0 & 0 & 15 & 1 \\
\hline Er. 26762 & $\begin{array}{c}\text { Lr26/Sr31/Pm8/Yr9 } \\
\text { Sr35 }\end{array}$ & $0-1$ & 0 & 0 & $0-1$ & 5 & 3 & $1-2 / 1-2$ & $1-2 / 1-2$ & $1-2 / 1-2$ & 0 & 0 & 1 & 1 \\
\hline Er. 26775 & Lr10 & $1-2$ & 3 & 3 & 0 & $3-4$ & 3 & $2-3 / 2-3$ & $2-3 / 2-3$ & $2-3 / 2-3$ & 0 & 0 & 5 & 0 \\
\hline M. 26690 & Lr1 Lr3 Lr10 & 0 & $0-1$ & $0-1$ & 0 & $3-4$ & $1-2$ & $1 / 1$ & $1 / 1$ & $1 / 1$ & 0 & 0 & 20 & 1 \\
\hline Ferr. 26774 & $\begin{array}{l}\text { Lr10 Lr21 } \\
\text { Lr34/Yr18/Sr57/Pm38 }\end{array}$ & $0-1$ & 0 & 0 & 0 & $2-3$ & $1-2$ & $2-3 / 2-3$ & $2-3 / 2-3$ & $1-2 / 2$ & 0 & 0 & 5 & 0 \\
\hline Chelyaba 75 & Lr1 Lr10 LrSp/SrSp & 0 & 0 & 0 & $1-2$ & $3-4$ & $2-3$ & $2-3 / 2-3$ & $2-3 / 2-3$ & $2-3 / 2-3$ & $1 \mathrm{MR}$ & 0 & 10 & 1 \\
\hline $\begin{array}{c}\text { Chelyaba } \\
\text { yubileynaya }\end{array}$ & Lr9 Lr10 & 3 & 0 & 0 & 3 & 4 & 3 & $3 / 3$ & $3 / 3$ & $2-3 / 2-3$ & $20 \mathrm{~S}$ & $\begin{array}{c}10-20 \\
\mathrm{~S}\end{array}$ & 5 & 5 \\
\hline Er. 59 & & $3-4$ & $3-4$ & $3-4$ & $3-4$ & 5 & 3 & $3 / 3$ & $3 / 3$ & $3 / 3$ & $30 \mathrm{~S}$ & $70 \mathrm{~s}$ & 20 & 10 \\
\hline
\end{tabular}

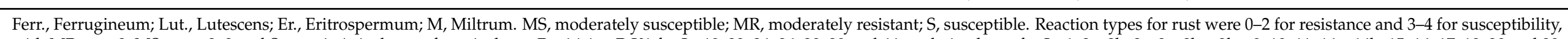

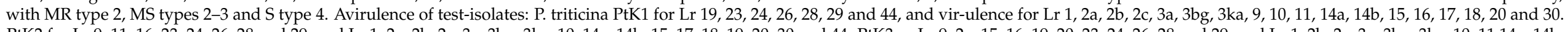

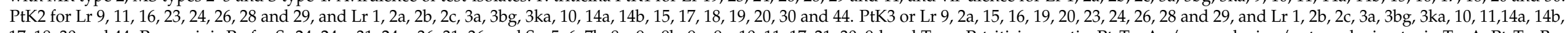

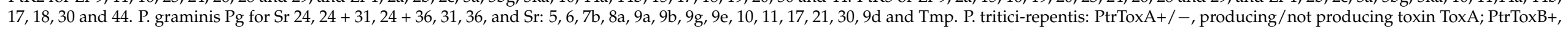

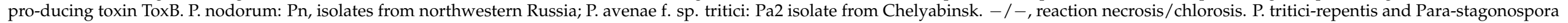

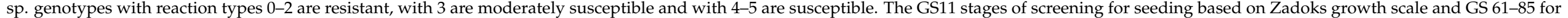
adult stages. 
Most of the introgressive lines are highly productive and have good grain and baking qualities. Lines Lut. 26708, Lut. 26720, Er. 26725, Ferr. 26727 (Ferrugineum), Er. 26762 and Er. 26755 are distinguished by relatively high productivity in combination with a high protein (15-16\%) and gluten (28-32\%) content, and good baking qualities (4.0 points).

\section{Variability of Pathogens' Population Structure in Response to Genetically Protected Cultivar Production}

Widespread adoption of genetically protected wheat cultivars can increase variability in pathogen populations. Resistance of cultivars to one pathogen produces a favorable niche for the development of another pathogen (in the absence of complex resistance). This can lead to a significant shift in the composition of pathogen populations. For successful disease genetic management, it is necessary to control the variability in pathogen populations and the effectiveness of resistance genes.

Leaf rust: Leaf rust is the most common and damaging of the wheat leaf diseases in the southern Ural. Until recently, most pathogen population research has focused on this pathogen [9,14,22-25]. Regional populations of $P$. triticina have been studied since 1981. From 1980 to the 2000s, there was no significant change in the composition of the pathogen populations. The dominance of the highly aggressive race 77 was consistent during that period. Since 1999, an increase in the frequency of virulence to the Thatcher (Tc) isogenic line with gene Lr19 was noted, a trend that continued until 2010. Cultivars protected by this gene were only grown to a limited extent in the southern Ural. However, they were widely grown in Volga regions bordering with Cis-Urals, and isolates virulent to the Lr19 gene dominated in these populations [25-27].

From 2014 to 2020, the main changes of regional leaf rust populations were associated with virulence to Lr9, Lr2a, Lr2b, Lr15, Lr20 and Lr26 (Figure 2). In 2019-2020, decreasing pathogen virulence was observed to most of these genes, excluding Lr9 and Lr26 (Figure 2). The now ineffective genes $(\operatorname{Lr} 9, \operatorname{Lr} 26, \operatorname{Lr} 10$ and $\operatorname{Lr} 1)$ are common in the spring wheat cultivars in the southern Ural, which lead to a high frequency of virulence in pathogen populations to these genes. However, no populations of the pathogen in the region were found to have virulence to both $\operatorname{Lr} 9$ and $L r 26$, or both $\operatorname{Lr} 19$ and $\operatorname{Lr} 26$. Virulence to $\operatorname{Lr} 9$ (or Lr19), and Lr1, Lr2a, Lr2b, Lr2c, Lr3a, Lr3bg, Lr3ka, Lr10, Lr14a, Lr14b, Lr15, Lr17, Lr18, Lr20 and $L r 30$ is widespread [22-25].

Resistance genes, Lr29, Lr41, Lr42, Lr45, Lr47, Lr50, Lr51, Lr53 and Lr57, have had high effectiveness in the southern Ural over a long period, as well as in other regions of Russia. Isolates virulent to TcLr24 and TcLr28 were detected before 2010, but not since [25]. Some of these genes are used in modern breeding in the southern Ural (e.g., Lr29, Lr45, Lr47 Lr53 and Lr57).

The dynamics of $P$. triticina races on some widely grown wheat cultivars (viz., Duet, Chelyaba 2, Chelyaba jubileynaya, Chelyaba rannyaya and Erythrospermum 59) are presented in Table 3 [22-24]. The main difference between southern Ural leaf rust populations and others in Russia is the high frequency of virulence to $\operatorname{Lr} 9$ (except those in West Siberia). This was presumably driven by widespread growing of cultivars with the Lr9 gene in the Ural and West Siberian regions. These long-term studies of regional P. triticina populations confirm the influence of genetically similar cultivars on the variability of pathogen populations and shifts in the composition of populations.

According to the index of genetic distances (Fst), no significant differences were found in the composition of the Chelyabinsk P. triticina populations in 2019-2020 (Fst $=0.11$, $p=0.08)$, although, they were moderately different from previous years (2014-2018). As shown above, the main variability of the Chelyabinsk populations affected the virulence frequencies to certain $L r$ genes, while no races with new virulence were identified during the period studied. 


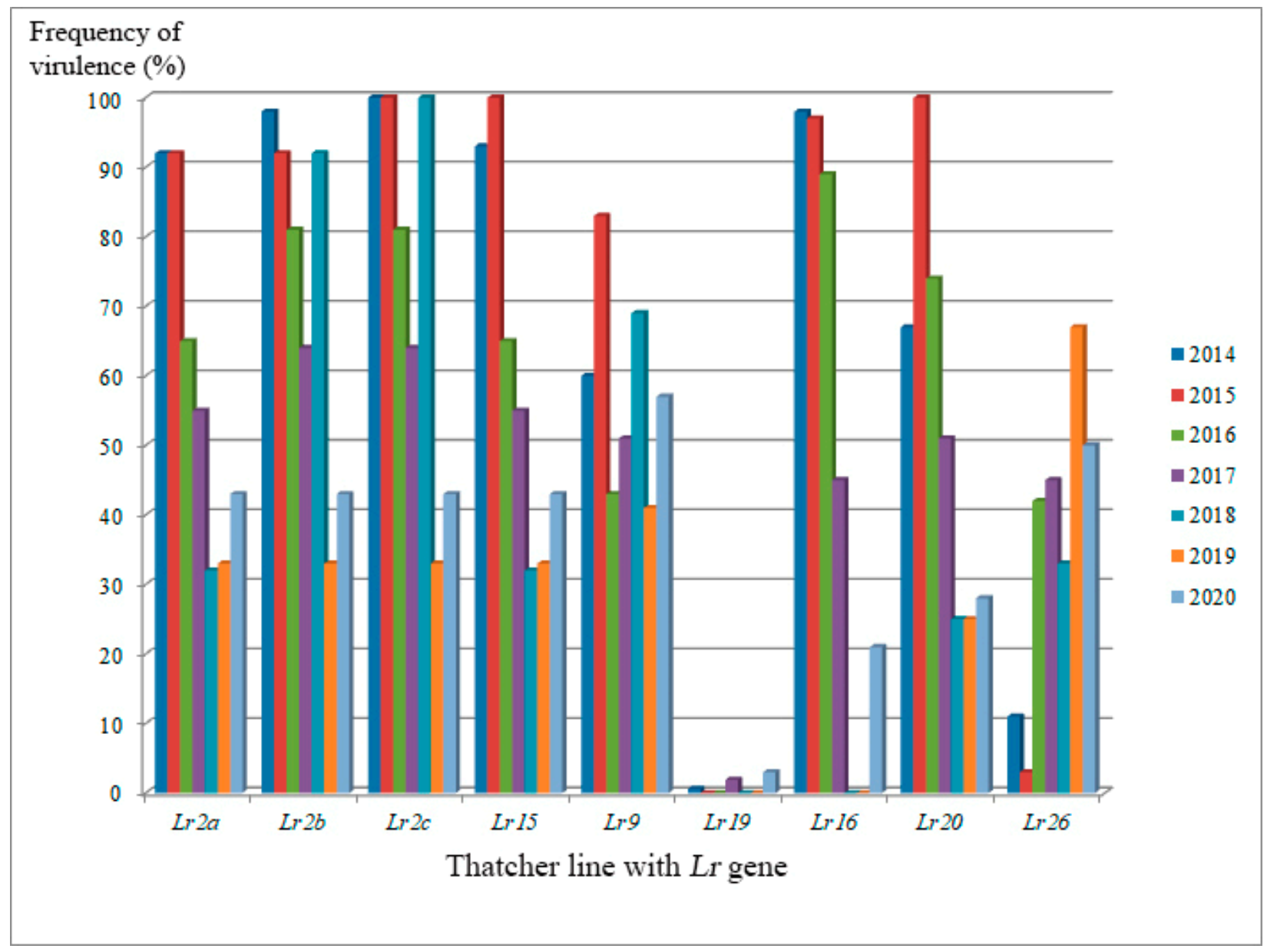

Figure 2. Virulence dynamics of the Chelyabinsk Puccinia triticina population (2014-2020).

Table 3. Races of $P$. triticina identified on widely grown spring wheat cultivars in Chelyabinsk region in 2014-2020.

\begin{tabular}{|c|c|c|c|c|c|c|c|}
\hline \multirow{2}{*}{ Wheat Cultivar } & \multicolumn{7}{|c|}{ P. triticina races } \\
\hline & 2014 & 2015 & 2016 & 2017 & 2018 & 2019 & 2020 \\
\hline Duet & $\begin{array}{l}\text { TQTTQ } \\
\text { TQTTR }\end{array}$ & TQTTR & PQTTG & MQPKH & PLPTG & TLTTR & TLTTR \\
\hline Chelyaba 2 & $\begin{array}{l}\text { TQTTQ } \\
\text { TQTTR }\end{array}$ & $\begin{array}{l}\text { TLTTR } \\
\text { TQTTR }\end{array}$ & TQPTR & MQPKG & PLPTG & MCTKG & TLTTR \\
\hline Chelyaba yubileynaya & TQTTR & TQTTR & TQTTR & MLTKG & PLTTG & MCTKG & - \\
\hline Chelyaba rannyaya & TQTTQ & TQTTRR & - & TQTTQ & PLTKG & MCTKG & TLTTR \\
\hline Eritrospermum 59 & $\begin{array}{l}\text { TGTTR } \\
\text { TQTTQ }\end{array}$ & $\begin{array}{l}\text { PGTKR } \\
\text { TQTTR }\end{array}$ & TGTTR & $\begin{array}{l}\text { MLTKH } \\
\text { THTTR }\end{array}$ & PLTTG & MCTKG & TCTTQ \\
\hline
\end{tabular}

A five-letter code describes virulence to 20 Thatcher near-isogenic wheat lines, as adapted from Long and Kolmer [28]. Virulence phenotypes were determined on a set of 20 differential lines (Set 1: $\operatorname{Lr} 1, \operatorname{Lr} 2 a, \operatorname{Lr} 2 c$ and $\operatorname{Lr} 3$; Set 2: Lr9, Lr16, Lr24 and Lr26; Set 3: Lr3ka, Lr11, Lr17 and Lr30; Set 4: Lr2b, Lr3bg, Lr14a and Lr14b; Set 5: Lr15, $L r 18, L r 19$ and $L r 20$ ) and binary encoded with 0 and 1 for avirulence and virulence, respectively. Reaction types on four ordered differentials in every set were encoded and designated by a letter using the hexadecimal code according to the corresponding binary quadruple.

Stem rust: Until recently, wheat stem rust of wheat in the southern Ural was absent or rare. However, it increased strongly by the end of the season in crops in the region during 2015-2017. In 2018-2020, stem rust was observed in crops to a weak to moderate degree, and again mostly by the end of the season. Consequently, stem rust population studies in the southern Ural had not been conducted. To characterize southern Ural pathogen population, the virulence analysis of the stem rust pathogen, Puccinia graminis, collected 
in the Chelyabinsk Oblast, was conducted in 2019-2020 using Marquis isogenic Sr lines. All isolates were avirulent to Marquis lines with genes Sr24, Sr24 + 31, Sr24 + 36, Sr31 and Sr36 (reaction types 0, 1 and 2), and virulent to Sr5, Sr6, Sr7b, Sr8a, Sr9a, Sr9b, Sr9g, Sr9e, Sr10, Sr11, Sr17, Sr21, Sr30, Sr9d and SrTmp (reaction types 3-4). The number of virulence alleles in the Chelyabinsk stem rust population in 2020 was slightly higher than in 2019 (15 and 11, respectively). Effectiveness of the Sr31 gene indicates that the Chelyabinsk $P$. graminis population does not contain isolates of the potentially damaging race Ug99. In terms of virulence, the Chelyabinsk P. graminis population was similar to the West Siberian populations [29].

Leaf blotches: The disease severity of leaf blotches on wheat under the conditions of the southern Ural varies between years from weak to moderate. Blotches usually in the field were estimated according to the total blotches disease severity without ascribing these to specific pathogen species, because the symptoms of leaf blotches are visually similar and are difficult to distinguish at the species level. In 2019-2020, for detailed clarification of pathogen populations, leaves with spots were collected from a large number of wheat samples and studied under laboratory conditions. This revealed that mixed septoria and tan spot infections occurred, with the latter dominating.

Tan spot: The recent increase in the importance of tan spot is due partly to reduced or zero-tillage practices that retain stubble on the soil surface, shorter crop rotations or continuous wheat cultivation. The tan spot causal agent, Pyrenophora tritici-repentis, is a necrotrophic fungus that produces host-specific toxins. The pathogen has the ToxA gene, which determines the production of necrosis inducing toxin PtrToxA in wheat cultivars having the avirulence gene Tsn1. In addition to necrosis on wheat leaves, chlorosis caused by toxins PtrToxB (race 5) and PtrToxC (race 3) develops. However, the main critical virulence factor is $\operatorname{PtrToxA}$ [30]. It has been shown that races producing exotoxin ToxA are potentially damaging (race 1, Tox $A+\operatorname{Tox} C$; race 2, Tox $A$; race 7, Tox $A+\operatorname{Tox} B$; race 8, Tox $A+$ Tox $B+\operatorname{Tox} C$ ) [31]. However, in our studies, wheat genotypes at the seedling stage mostly had similar reactions to Ptr isolates producing different toxins (Table 2).

Characterization of $P$. tritici-repentis isolates is important for developing resistant wheat cultivars. The virulence of $P$. tritici-repentis isolates on differential wheat lines/cultivars grown in Chelyabinsk was determined in 2017, and 2019-2020. Pathogenic races of P. tritici-repentis have been characterized according to their ability to induce necrosis and/or chlorosis on differential wheat lines/cultivars (lines 6B365 and line 6B662, and cv. Glenlea): 6B365 has Tsc1, the gene controlling sensitivity to PtrToxC (races 1, 3, 6 and 8), 6B662 has $T s c 2$, the gene controlling sensitivity to Ptr ToxB (races 5, 6, 7 and 8), and cv. Glenlea has Tsn1, the gene controlling sensitivity to PtrToxA (races 1, 2, 7 and 8) [32].

In 2017, wheat leaves with spots were collected from samples studied in Chelyabinsk under the Kazakhstan-Siberia Network for the Spring Wheat Improvement program [24]. Nineteen monoconidial isolates of $P$. tritici-repentis were assessed and five races were determined (Table 4). The highest proportion was in races producing PtrToxA toxin (86\%).

Table 4. Frequency of Pyrenophora tritici-repentis races in Chelyabinsk region on spring soft wheat (\%).

\begin{tabular}{ccccc}
\hline Race & Ptr Toxins & $\mathbf{2 0 1 7}$ & $\mathbf{2 0 1 9}$ & $\mathbf{2 0 2 0}$ \\
\hline 1 & PtrToxA, ToxC & 26 & 2 & 32 \\
2 & ToxA & 53 & 8 & 11 \\
3 & ToxC & 0 & 3 & 8 \\
4 & No toxins & 5 & 29 & 27 \\
5 & PtrToxB & 0 & 14 & 0 \\
6 & ToxB + Tox & 0 & 12 & 8 \\
7 & ToxA $A$ ToxB & 5 & 16 & 0 \\
8 & ToxA ToxB ToxC & 7 & 16 & 11 \\
Number of isolates & & 19 & 86 & 37
\end{tabular}


In 2019 and 2020, infected leaves were collected from ChRIA breeding lines and cultivars. Eighty-six isolates were analyzed in 2019 and 37 in 2020 (Table 4). The highest incidence $(29 \%)$ was of race 4 (Tox-), which does not produce toxins. The incidence of other races that do not produce ToxA (race 5, ToxB; race 6 ToxB + ToxC; race 3, ToxC) was 29\%. Overall, the incidence of the non-ToxA-producing group of races was $58 \%$. In 2019 , these races predominated on cultivars and breeding lines with translocations from Ae. speltoides (69\%), Aegilops tauschii (66\%) and Aegilops umbellilata + Secale cereale (75\%). In lines having a translocation from Thinopyrum ponticum (=Agropyron elongatum), the incidence was slightly lower than $49 \%$. These wild relatives of wheat have long been known to have superior resistance to various diseases. They can be crossed with wheat, making them a potential source of genes for wheat improvement [33].

In 2019-2020, we conducted a comparative analysis of $P$. tritici-repentis race composition on genetically different spring wheat introgressive breeding lines (Table 5). This made it possible to assess the influence of various alien translocations on the pathogen race development. On genetically heterogeneous introgressive lines, a high diversity of the pathogen races was revealed as well as a wide variation between years. There was no correlation between the presence of a translocation from Ae. speltoides providing protection against leaf $(L r S p)$ and stem $(S r S p)$ rusts, and resistance to tan spot previously noted by Mikhailova et al. [31].

Table 5. Races of Pyrenophora tritici-repentis on introgressive soft wheat breeding lines in 2019-2020 in Chelyabinsk region in 2019-2020.

\begin{tabular}{|c|c|c|c|}
\hline \multirow{2}{*}{ Line } & \multirow{2}{*}{ Pedigree (Alien Genetic Material) } & \multicolumn{2}{|c|}{ Race Number } \\
\hline & & 2019 & 2020 \\
\hline Ferr. 26758 & $\begin{array}{l}\text { Chelyaba } 75 \times \text { Ferr. } 24205 \\
(\text { Ae. speltoides })\end{array}$ & $\begin{array}{c}4(\text { Tox }-) \\
7(\text { Tox } A+\text { To } x B)\end{array}$ & $6(\operatorname{Tox} B+\operatorname{Tox} C)$ \\
\hline Ferr. 26754 & $\begin{array}{c}\text { Chelyaba } 75 \times \text { Ferr. } 24205 \\
(\text { Ae. speltoides })\end{array}$ & & $3($ Tox $C), 4($ Tox- $)$ \\
\hline Ferr. 26680 & $\begin{array}{c}\text { Er.59 } \times \text { TcLr22a } \times \text { Iren' } \times \text { Chelyaba } 75 \\
(\text { Ae. tauschii, Ae. speltoides })\end{array}$ & $4($ To $x-)$ & $4($ Tox- $)$ \\
\hline Lut. 26509 & $\begin{array}{c}\text { Er. } 23315 \times \text { Ecada } 45 \\
(\text { Ae. speltoides })\end{array}$ & $\begin{array}{c}3(\text { Tox } C) \\
8(\text { Tox } A+\text { ToxB }+ \text { Tox } C)\end{array}$ & $\begin{array}{c}2(\text { ToxA }), 3(\text { ToxC }) \\
4(\text { To } x-)\end{array}$ \\
\hline Ferr. 26635 & Sharada × Ferr. 23736 & $\begin{array}{c}4(\text { To } x-) \\
7(\text { Tox } A+\text { Tox } B)\end{array}$ & $\begin{array}{c}1(\text { Tox } A+\text { ToxC }) \\
2(\text { ToxA })\end{array}$ \\
\hline Er. 26751 & $\begin{array}{c}\text { Chelyaba } 75 \times \text { Ferr. } 24205 \\
(\text { Ae. speltoides })\end{array}$ & $4($ Tox -$), 5($ ToxB $)$ & $1(\operatorname{Tox} A+\operatorname{Tox} C)$ \\
\hline Er. 26726 & $\begin{array}{c}\text { Ferr. } 23736 \times \text { Lut. } 23814 \\
(\text { Ag. elongatum, Ae. umbellulaya })\end{array}$ & $7(\operatorname{Tox} A+\operatorname{Tox} B)$ & $\begin{array}{c}1(\operatorname{Tox} A+\operatorname{Tox} C) \\
4(\text { To } x-)\end{array}$ \\
\hline Er.26752 & $\begin{array}{c}\text { Chelyaba } 75 \times \text { Ferr. } 24205 \\
(\text { Ae. speltoides })\end{array}$ & $\begin{array}{c}5(\text { ToxB }) \\
6(\operatorname{Tox} B+\operatorname{Tox} C)\end{array}$ & $\begin{array}{c}1(\operatorname{Tox} A+\operatorname{Tox} C) \\
3(\operatorname{Tox} C), 4(\text { Tox }-) \\
8(\operatorname{Tox} A+\text { Tox } B+\text { Tox } C)\end{array}$ \\
\hline Er. 26677 & $\begin{array}{c}\text { Er.59 } \times \text { TcLr22a } \times \text { Iren' } \times \text { Chelyaba } 75 \\
(\text { Ae. tauschii, Ae. speltoides })\end{array}$ & $\begin{array}{c}5(\text { ToxB }) \\
8(\text { Tox } A+\text { ToxB }+ \text { Tox } C)\end{array}$ & $\begin{array}{c}1(\operatorname{Tox} A+\operatorname{Tox} C) \\
2(\operatorname{Tox} A) \\
8(\operatorname{Tox} A+\operatorname{Tox} B+\operatorname{Tox} C)\end{array}$ \\
\hline Er. 26740 & $\begin{array}{c}\text { Chelyaba } 75 \times \text { Apasovka } \\
(\text { Ae. speltoides, Ae. umbellulaya })\end{array}$ & $\begin{array}{l}6(\operatorname{Tox} B+\operatorname{Tox} C) \\
7(\operatorname{Tox} A+\operatorname{Tox} B)\end{array}$ & $\begin{array}{c}4(\text { To } x-) \\
6(\text { ToxB }+ \text { Tox } C)\end{array}$ \\
\hline
\end{tabular}

It is suggested that the increase in disease was due to changes in agricultural practices as well as pathogen acquisition of a potent virulence/pathogenicity factor, ToxA, by horizontal gene transfer. To better understand the mechanisms that have led to the increase in tan spot disease incidence, Manning et al. [34] sequenced the genomes of three P. triticirepentis isolates. Comparison of genomes of pathogenic (produced host-selective toxins) and non-pathogenic isolates showed that the genome of non-pathogenic isolates diverged more. Examination of gene-coding regions has provided candidate pathogen-specific proteins and revealed gene families that may enable to necrotrophic pathogenicity. Analysis of transposable elements suggests that their presence in the genome of pathogenic isolates 
contributes to the creation of novel genes, effector diversification, possible horizontal gene transfer events, identified copy number variation and the first example of trans-duplication by DNA transposable elements [34].

Aboukhaddour et al. [35] conducted a large-scale karyotype study of P. tritici-repentis including isolates from the eight standard races and from diverse geographical origins. The $P$. tritici-repentis genome was found to have extensive chromosomal polymorphism indicative of its plasticity. Karyotypes were as diverse within as across races. Chromosomal polymorphism of toxin genes carrying chromosomes has been observed for both chromosome size and number (one or two). ToxA and ToxB have been shown to be on different chromosomes, and the chromosome on which ToxA is normally found is homologous among isolates and appears to be of an essential nature [35].

The high plasticity of $P$. tritici-repentis fungus determines the significance of this disease in the southern Ural. The advanced selections for this disease will be important for its management in wheat production systems.

Septoria leaf blotch: Septoria leaf blotch, unlike tan spot, is a more problematic wheat disease in the southern Ural and occurs annually, with low or medium severity. In 2019-2020, monoconidial isolates were obtained from wheat leaves with pycnidia collected from ChRIA cultivars and breeding lines for clarification of pathogen species. An analysis was performed using the sequencing of the internal transcribed spacer of rDNA (ITS) and the beta-tubulin gene fragment. It was revealed that along with Parastagonospora nodorum in 2019, there were common occurrences of Parastagonospora avenae $\mathrm{f}$. sp. tritici in the region, but in 2020, only to $P$. nodorum. Distinguishing P. nodorum and P. avenae f. sp. tritici is difficult because the main difference is the size of the conidia, but the size ranges can overlap. Additionally, the resistance of wheat genotypes to these two species is different, so this should be considered in regional breeding programs.

P. nodorum (teleomorph: Phaeosphaeria nodorum), formerly known as Septoria nodorum and Stagonospora nodorum (teleomorph: Leptosphaeria nodorum), is the main species of three Parastagonospora taxa-infecting cereals (also including P. avenae and P. avenae f. sp. tritici). $P$. avenae infects oat, and there is subgroup within $P$. avenae which are non-pathogenic on oat, but infect wheat and barley, and have been named P. avenae f. sp. tritici [36].

The lack of a set of differentiating cultivars for studying the virulence to septoria leaf blotch caused by $P$. nodorum makes it impractical for us to assess the race composition of this pathogen. However, P. nodorum, P. tritici-repentis and other related species within the leaf spot complex are known for their ability to secrete several necrotrophic effectors, previously known as host-selective toxins, which are often proteins that act as virulence factors and mediate disease development through an inverse gene-for-gene interaction [37]. $P$. nodorum produces several necrotrophic effectors that act as virulence factors, and three have been cloned, SnToxA, SnTox1 and SnTox3. Therefore, the inability to easily distinguish this agent is a constraint to resistance breeding.

The presence of SnToxA, SnTox1 and SnTox3 in Chelyabinsk isolates P. nodorum and P. avenae f. tritici was determined by PCR using specific markers (SnTox1c, SnTox3cF [38], ToxA192/ToxA1155, ToxA (TA51F/TA51R)) [38,39]. All P. nodorum isolates showed the presence of the SnTox3 marker. This marker was also detected in P. avenae f. sp. tritici isolates, but its amplification was weaker. SnToxA genes were found in $40 \%$ of P. nodorum isolates and the SnTox 1 gene in $60 \%$. Usually, these genes occurred separately, but in one isolate, they were found together (unpublished data). None of the studied toxins were detected in isolates of $P$. avenae f. sp. tritici, which indicates their low aggressiveness compared to $P$. nodorum. This information is consistent with the results of Chelyabinsk soft wheat inoculation testing. The aggressiveness of $P$. nodorum isolates was significantly higher than that of P. avenae f. sp. tritici (Table 2).

\section{Conclusions}

This article presented an analysis of wheat genetic variability in the southern Ural, Russia, in terms of population compositions of their obligate and hemibiotrophic 
pathogen complexes. This helps in understanding plant reactions when they are exposed to multiple pathogens with differing mechanisms of infection and pathogenicity under conducive conditions.

The analysis of the genetic diversity of wheat cultivars grown in the southern Ural, and the pathogenic complex present, indicate that pathogens continuously evolve into novel virulent races. Since leaf rust is the most damaging pathogen in the southern Ural, breeders need to develop cultivars resistant to this disease. The importance of stem rust and leaf blotches increased in the 2010s, when cultivars with the Lr9 gene began to be widely grown in the region. These cultivars were resistant to leaf rust but susceptible to stem rust and leaf blotches. Thus, cultivar resistance to leaf rust provides an opportunity for colonization of leaves by other pathogens. After 10 years of commercial wheat farming, the $\operatorname{Lr} 9$ gene has lost effectiveness. However, in the 2010s, the ranged of commercial wheat cultivars grown in the region was expanded to include cultivars having other racespecific resistance genes. The common production of moderately susceptible or only moderately resistant wheat cultivars in farming in the southern Ural, along with changes in agricultural practices, has led to pathogen build-up and providing abundant inoculum to initiate disease cycles, and provided favorable conditions for the leaf blotches to increase in their importance. In addition to these factors, the influence of global climate change favoring disease development in the region cannot be excluded. Knowledge of genetic variation in a pathogen population underpins breeding for disease resistance. Long-term monitoring of the leaf rust pathogen populations in the southern Ural has not revealed significant changes in the pathogen virulence since the 2010s. In 2019-2020, there was a moderate decrease in the frequency of pathogen virulence to a number of $L r$ genes. This indicates some stability in the genetic management of wheat in the region for this pathogen. However, significant variation in susceptibility to P. tritici-repentis and Parastagonospora races was found; in particular, potentially damaging races of $P$. tritici-repentis producing the exotoxin ToxA were found.

Microevolutionary changes in populations of the tan spot pathogen increase genetic diversity, allowing expansion into new areas and increasing virulence in comparison to previous populations [40]. The southern Ural is an area where $P$. tritici-repentis has appeared recently. Pathogen populations adjust to their environment over time, but the dynamics of emerging pathogens can be difficult to predict. According to Mikhailova et al. [31], the virulence structure is an indicator of population age. Older populations have lower virulence, as natural selection operates against excess virulence. The Tsn1 gene is not present in most wheat cultivars grown in the southern Ural, but some ChRIA wheat genotypes were susceptible to race PtrToxA.

Under co-infection conditions, pathogens are thought to exploit host-limited resources more efficiently, with natural selection favoring the coexistence of pathogens that are less damaging to their hosts [41,42]. Early during co-infection, the more virulent pathogen may quickly dominate. However, similarly virulent pathogens can coexist and share their hosts, mainly due to conditions favoring the occurrence of multiple pathogens [43]. An unresolved question is how changes in natural (e.g., climate) and man-made (e.g., new cultivars with polygenic or major gene resistances) conditions alter coexistence in the long term. Changes to conditions may favor one pathogen over another, potentially leading to epidemics of more aggressive pathogens [44]. Therefore, to make significant progress in wheat disease management, research efforts need to include field evaluations encompassing the range of environmental conditions and multiple-pathogen infections.

Author Contributions: Conceptualization, I.K. and E.G.; methodology, E.S. (Ekaterina Shreyder), N.B., N.K., E.S. (Ekaterina Shaydayuk) and E.G.; validation, E.S. (Ekaterina Shreyder), N.B., N.K. and E.S. (Ekaterina Shaydayuk); formal analysis, I.K., J.T. and E.G.; investigation, I.K., E.S. (Ekaterina Shreyder), N.B., N.K., E.S. (Ekaterina Shaydayuk) and E.G.; data curation, I.K., E.S. (Ekaterina Shreyder) and E.G.; writing-original draft preparation, I.K., J.T. and E.G. All authors have read and agreed to the published version of the manuscript. 
Funding: This study was funded by the RFBR grant No. 19-016-00052.

Institutional Review Board Statement: Not applicable.

Informed Consent Statement: Not applicable.

Data Availability Statement: All data are provided in the manuscript.

Acknowledgments: Editorial support of Ian Riley is highly appreciated.

Conflicts of Interest: The authors declare no conflict of interest.

\section{References}

1. Sysoev, A.D. Essays on the Physical Geography of the Chelyabinsk Region; Chelyabinskoie Knizhnoe Izd-Vo: Chelyabinsk, Russia, 1959; 205p. (In Russian)

2. Levit, L.I. Southern Urals: Geography, Environmental Management; Yuzh.Ural.kn.izd-vo: Chelyabinsk, Russia, 2001; 245p. (In Russian)

3. Ryub, V.K. Results and Prospects of Work on the Selection of Spring Wheat; Collection of Scientific Papers; Yuzh.Ural.kn.izd-vo: Chelyabinsk, Russia, 1970; Volume 3, pp. 150-170. (In Russian)

4. Ryub, V.K. Some Results of Breeding Work with Spring Wheat as a Result of the Use of Samples from the World Collection of VIR in Hybridization; Proceeding of Scientific Papers; Chelyab. Experimental Station: Chelyabinsk, Russia, 1973; Volume 4, pp. 6-15. (In Russian)

5. Expert and Analytical Center for Agribusiness. Available online: https://ab-centre.ru/page/selskoe-hozyaystvo-chelyabinskoyoblasti (accessed on 10 May 2021).

6. Agrovestnik. Available online: https://agrovesti.net/lib/industries/cereals/posevnye-ploshchadi-valovye-sbory-i-urozhajnostpshenitsy-v-rossii-itogi-2018-goda.html (accessed on 10 May 2021).

7. Tyunin, V.A. Ecological substantiation of requirements to breeds of soft spring wheat for Southern Ural. Orenbg. State Univ. Bull. 2005, 5, 122-124. (In Russian)

8. Tyunin, V.A.; Shreyder, E.R. Features of the Technology of Selection of Soft Spring Wheat for Resistance to Carbohydrate-Protein Depletion of Seeds and Other Stresses in the Conditions of the Southern Urals; Russian Academy of Agricultural Sciences, State Scientific Institution Chelyabinsk Scientific Research, Institute of Agriculture: Chelyabinsk, Russia, 2010; 119p. (In Russian)

9. Meshkova, L.V.; Rosseeva, L.P.; Shreyder, E.R.; Sidorov, A.V. Virulence of pathotypes of wheat leaf rust pathogen to TcLR 9 in the regions of Siberia and the Urals. In Proceedings of the the Second All-Russian Conference "Modern Problems of Plant Immunity to Harmful Organisms", St. Petersburg, Russia, 29 September-2 October 2008; pp. 70-73. (In Russian)

10. Gultyaeva, E.; Tyunin, V.; Shreyder, E.; Kushnirenko, I.; Shaydayuk, E.; Kovalenko, N.; Bondarenko, N.; Kolesova, M. Breeding of spring bread wheat for resistance to foliar diseases in the southern Ural. Russ. Agric. Sci. 2021, 8-12. [CrossRef]

11. Gultyaeva, E.I.; Baranova, O.A.; Dmitriev, A.P. Virulence and population structure of Puccinia triticina in Russian Federation in 2007. Plant Prot. News 2009, 4, 33-38. (In Russian)

12. Odintsova, I.G.; Agafonova, N.A.; Boguslavsky, R.L. Introgressive lines of common wheat with resistantance to leaf rust transferred from Aegilops speltoides, in Source material and problems of wheat and triticale breeding. Proc. Appl. Botany. Genet. Breed. 1991, 142, 106-110. (In Russian)

13. Ibraimova, Z.K.I.; Tankimanova, M.K.; Bersimbaev, R.I. Chromosomal localization of the gamete-killing gene in the wheat line. Tsitol Genet. 2001, 35, 15-19. (In Russian)

14. Tyunin, V.A.; Shreyder, E.R.; Gultyaeva, E.I.; Shaydayuk, E.L. Characteristics of virulence of Puccinia triticina populations and the potential of the Lr24, Lr25, LrSp genes for spring common wheat breeding in the Southern Ural. Vavilov J. Genet. Breed. 2017, 21, 523-529. [CrossRef]

15. Adonina, I.G.; Leonova, I.N.; Badaeva, E.D.; Salina, E.A. Genotyping of hexaploid wheat varieties from different Russian regions. Russ. J. Genet. Appl. Res. 2017, 7, 6-13. [CrossRef]

16. Gultyaeva, E.I.; Orina, A.S.; Gannibal, P.B.; Mitrofanova, O.P.; Odintsova, I.G.; Laikova, L.I. The effectiveness of molecular markers for the identification of Lr28, Lr35, and Lr47 genes in common wheat. Genetika 2014, 50, 147-156. [CrossRef]

17. Marais, G.F.; Bekker, T.A.; Eksteen, A.; McCallum, B.D.; Fetch, T.G.; Marais, A. Attempts to remove gametocidal genes cotransferred to common wheat with rust resistance from Aegilops speltoides. Euphytica 2009, 171, 71-85. [CrossRef]

18. Morgounov, A.; Pozherukova, V.; Kolmer, J.; Gultyaeva, E.; Abugalieva, A.; Chudinov, V.; Kuzmin, O.; Rasheed, A.; Rsymbetov, A.; Shepelev, S.; et al. Genetic basis of spring wheat resistance to leaf rust (Puccinia triticina) in Kazakhstan and Russia. Euphytica 2020, 216, 1-15. [CrossRef]

19. Gultyaeva, E.I.; Shreyder, E.R.; Kushnirenko, I.Y.; Shaydayuk, E.L.; Kovalenko, N.M. Evaluation of advanced bread spring wheat lines for field and seedling resistance to foliar pathogens. In BIO Web of Conferences; EDP Sciences: Les Ulis, France, 2020. [CrossRef]

20. Zhang, Z.; Friesen, T.L.; Simons, K.J.; Xu, S.S.; Faris, J.D. Development, identification, and validation of markers for markerassisted selection against the Stagonospora nodorum toxin sensitivity genes Tsn1 and Snn2 in wheat. Mol. Breed. 2008, 23, 35-49. [CrossRef] 
21. Sibikeev, S.N.; Badaeva, E.D.; Gultyaeva, E.I.; Druzhin, A.E.; Shishkina, A.A.; Dragovich, A.Y.; Kroupin, P.Y.; Karlov, G.I.; Khuat, T.M.; Divashuk, M.G. Comparative analysis of Agropyron intermedium (Host) Beauv 6Ag i and 6Ag i 2 chromosomes in bread wheat cultivars and lines with wheat-wheatgrass substitutions. Russ. J. Genet. 2017, 53, 314-324. [CrossRef]

22. Tyunin, V.; Shreyder, E.; Gultyaeva, E.; Shaydayuk, E. Virulence of leaf rust pathogen of wheat in South Ural. Plant Prot. News 2018, 1, 16-20. [CrossRef]

23. Gultyaeva, E.I.; Shreyder, E.; Shaydayuk, E.; Bondarenko, N. Monitoring of virulence and phenotypes composition of Puccinia triticina population in southern ural in 2018. Plant Prot. News 2019, 2, 28-33. [CrossRef]

24. Gultyaeva, E.I.; Kovalenko, N.M.; Shamanin, V.P.; Tyunin, V.A.; Shreyder, E.R.; Shaydayuk, E.L.; Morgunov, A.I. Population structure of leaf pathogens of common spring wheat in the west Asian regions of Russia and north Kazakhstan in 2017. Vavilov J. Genet. Breed. 2018, 22, 363-369. [CrossRef]

25. Gultyaeva, E.I.; Shaydayuk, E.L.; Kosman, E.G. Regional and temporal differentiation of virulence phenotypes of Puccinia triticina from common wheat in Russia during the period 2001-2018. Plant Pathol. 2020, 69, 860-871. [CrossRef]

26. Markelova, T.S. Study of population structure and variability of wheat leaf rust population in the Volga region. Agro XXI 2007, 4-6. Available online: https:/ / www.agroxxi.ru/journal/20070406/20070406018.pdf (accessed on 26 July 2021). (In Russian)

27. Zhemchuzhina, A.; Kiseleva, M.; Zhemchuzhina, N.; Belyakova, S. Virulence of Puccinia triticina Erikss. Population in nonchernozem area of Russia. Agrar. Sci. 2019, 326, 137-141. (In Russian) [CrossRef]

28. Long, D.L.; Kolmer, J.A. A North American system of nomenclature for Puccinia recondita f. sp. tritici. Phytopathology 1989, 79, 525-529. [CrossRef]

29. Skolotneva, E.S.; Kosman, E.; Patpour, M.; Kelbin, V.N.; Morgounov, A.I.; Shamanin, V.P.; Salina, E.A. Virulence phenotypes of siberian wheat stem rust population in 2017-2018. Front. Agron. 2020, 2, 6. [CrossRef]

30. Lamari, L.; Gilbert, J.; Tekauz, A. Race differentiation in Perynophora tritici-repentis and survey of physiologic variation in western Canada. Can. J. Plant Pathol. 1998, 20, 396-400. [CrossRef]

31. Mikhailova, L.A.; Kokorina, N.M.; Kopahnke, D. Genetics of tan spot (Pyrenophora tritici-repentis) resistance in spring wheat lines 181-5, Vicam“'S"70, 292. Russ. Agric. Sci. 2003, 1, 20-22. (In Russian)

32. Friesen, T.L.; Ali, S.; Klein, K.K.; Rasmussen, J.B. Population genetic analysis of a global collection of Pyrenophora tritici-repentis, causal agent of tan spot of wheat. Phytopathology 2005, 95, 1144-1150. [CrossRef] [PubMed]

33. Wang, R.R.-C. Agropyron and Psathyrostachys. In Wild Crop Relatives: Genomic and Breeding Resources; Springer: Berlin, Germany, 2011; pp. 77-108. [CrossRef]

34. Mikhailova, L.A.; Ternuk, I.G.; Mironenko, N.V. Characteristic of Pyrenophora tritici-repentis populations by their virulence. Mikol. Phytopathol. 2010, 44, 262-272. (In Russian)

35. Manning, V.A.; Pandelova, I.; Dhillon, B.; Wilhelm, L.J.; Goodwin, S.; Berlin, A.M.; Figueroa, M.; Freitag, M.; Hane, J.; Henrissat, B.; et al. Comparative Genomics of a Plant-Pathogenic Fungus, Pyrenophora tritici-repentis, Reveals Transduplication and the Impact of Repeat Elements on Pathogenicity and Population Divergence. G3: Genes Genomes Genet. 2013, 3, 41-63. [CrossRef]

36. Aboukhaddour, R.; Cloutier, S.; Ballance, G.M.; Lamari, L. Genome characterization ofPyrenophora tritici-repentisisolates reveals high plasticity and independent chromosomal location of ToxA and ToxB. Mol. Plant Pathol. 2009, 10, 201-212. [CrossRef] [PubMed]

37. Hafez, M.; Gourlie, R.; Despins, T.; Turkington, T.K.; Friesen, T.L.; Aboukhaddour, R. Parastagonospora nodorumand Related Species in Western Canada: Genetic Variability and Effector Genes. Phytopathology 2020, 110, 1946-1958. [CrossRef] [PubMed]

38. Friesen, T.L.; Meinhardt, S.W.; Faris, J. The Stagonospora nodorum-wheat pathosystem involves multiple proteinaceous hostselective toxins and corresponding host sensitivity genes that interact in an inverse gene-for-gene manner. Plant J. 2007, 51, 681-692. [CrossRef]

39. Gao, Y.; Faris, J.; Liu, Z.; Kim, Y.M.; Syme, R.; Oliver, R.P.; Xu, S.S.; Friesen, T.L. Identification and characterization of the SnTox6-Snn6 interaction in the Parastagonospora nodorum-wheat pathosystem. Mol. Plant-Microbe Interact. 2015, 28, 615-625. [CrossRef]

40. Friesen, T.L.; Stukenbrock, E.H.; Liu, Z.; Meinhardt, S.; Ling, H.; Faris, J.; Rasmussen, J.B.; Solomon, P.; McDonald, B.; Oliver, R.P. Emergence of a new disease as a result of interspecific virulence gene transfer. Nat. Genet. 2006, 38, 953-956. [CrossRef]

41. Andrie, R.M.; Pandelova, I.; Ciuffetti, L.M. A combination of phenotypic and genotypic characterization strengthens Pyrenophora tritici-repentis race identification. Phytopathology 2007, 97, 694-701. [CrossRef]

42. Brown, S.P.; Hochberg, M.E.; Grenfell, B.T. Does multiple infection select for raised virulence? Trends Microbiol. 2002, 10, 401-405. [CrossRef]

43. Van Baalen, M.; Sabelis, M.W. The scope for virulence management: A comment on Ewald's view on the evolution of virulence. Trends Microbiol. 1995, 3, 414-416. [CrossRef]

44. Abdullah, A.S.; Moffat, C.S.; Lopez-Ruiz, F.J.; Gibberd, M.R.; Hamblin, J.; Zerihun, A. Host-multi-pathogen warfare: Pathogen interactions in co-infected plants. Front. Plant. Sci. 2017, 8, 1806. [CrossRef] 